\title{
Hypereosinophilic syndrome
}

INSERM

\section{Source}

INSERM. (1999). Orphanet: an online rare disease and orphan drug data base.

Hypereosinophilic syndrome. ORPHA:168956

Hypereosinophilic syndrome (HES) constitutes a rare and heterogeneous group of disorders, defined as persistent and marked blood eosinophilia and/or tissue eosinophilia associated with a wide range of clinical manifestations reflecting eosinophil-induced tissue/org an damage. 